\title{
The influence of auditor term length and term limits on US state general obligation bond ratings
}

\author{
Mark Schelker
}

Received: 2 September 2009 / Accepted: 28 June 2010 / Published online: 27 July 2010

(C) Springer Science+Business Media, LLC 2010

\begin{abstract}
Improving transparency and enabling the principal to hold its agents accountable is a major issue in any principal agent relationship. This paper focuses on the role of public auditors in this task and presents evidence on the impact of auditor term length and term limits on government performance measured by state credit ratings at the US State level. I find no clear evidence for the influence of auditor term length, but strong evidence for a positive and significant influence of term limits on state credit ratings. Auditors who face a binding term limit are associated with higher credit ratings.
\end{abstract}

Keywords Public auditor · Term length · Term limit · Credit rating · Fiscal policy

JEL Classification $\mathrm{H} 83 \cdot \mathrm{D} 70 \cdot \mathrm{H} 10$

\section{Introduction}

The incentives provided by any institutional arrangement crucially impact on the behavior of agents within that framework. The public sector is characterized by delegation hierarchies involving manifold principal-agent relationships. In order to control the agents developed democracies feature complex systems of checks and balances and supervising institutions that should help in holding government agents accountable. This study focuses on public auditing institutions which are mandated to supervise public officials and improve transparency in the public sector.

The office of the public auditor is one of the main supervising institutions in such systems. Usually, audit offices are fairly large bureaucracies: e.g., the US federal audit agency alone, the Government Accountability Office (GAO), has a budget of roughly half a billion USD, and the German Bundesrechungshof and its associated offices employ more than

M. Schelker (凶)

Swiss Institute for International Economics and Applied Economic Research (SIAW), University of St. Gallen, Bodanstrasse 8, 9000 St. Gallen, Switzerland

e-mail: mark.schelker@unisg.ch 
1400 individuals. Despite these facts, there is almost no economic research on public auditing institutions. Auditors conduct financial audits and various forms of performance audits and are supposed to serve as watch-dogs over the executive and the bureaucracy to insure accurate reporting by government agencies, improve transparency, fight misappropriation, fraud, corruption, wasteful usage of public funds and general inefficiencies. Since the auditor is also an appointed agent who has to supervise other agents, the question of how auditor accountability affects public sector performance is essential.

This paper analyzes the influence of auditor term length and term limits on fiscal outcomes. Term length and term limits are crucial since they shape incentives of public auditors. These aspects have not been the subject of economic analyses even thought they proved to significantly influence accountability and auditor performance in the corporate sector. The debate on the topic of tenure length and mandatory auditor rotation in corporate auditing, which is closely related to term limits in the public sector, is intense and an extensive body of research has been published. In the public sector the effect of term length and term limits has been the subject of research in political economy for public offices in the executive and the legislative, but not for auditors. This analysis combines these strands of economic research to gain insights into the hitherto unexplored area of public sector auditing. The empirical analysis is conducted for the US states in which public auditing institutions differ with respect to the length of office terms and the existence of term limits. I exploit a unique dataset and analyze the influence of auditor term length and term limits on state credit ratings for 42 states from 1990 to 1999.

The theoretical discussion of Sect. 2 introduces the literature on the role and influence of public auditing institutions and presents the available evidence on term length and term limits for public officials (legislative and executive mandates) as well as for corporate auditors. I integrate the outlined theoretical considerations to formulate testable hypotheses on the influence of auditor term length and term limits. Moreover, this section establishes explicitly the link between auditor characteristics and fiscal outcomes measured by state credit ratings. Section 3 contains the empirical part of the paper. It starts with a presentation of US state auditing institutions, continues with a description of the respective data and the empirical strategy, and finally presents and discusses the empirical results. Section 4 summarizes and concludes.

\section{Auditor basics, term length and term limits}

\subsection{Auditor basics}

The fundamental agency problem between citizens and their agents in government positions is well established. In order to control the agent, the principal requires information. Such information is typically revealed through some procedural mechanism of agent himself or by some third party. In many cases the information is reviewed by an external body in order to insure the accuracy of the information provided. In the political process the quality and quantity of the available information is heavily determined by transparency and supervision requirements. Research on the influence of transparency in the budget process shows that improved transparency reduces information asymmetries between principal and agent and enhances government performance (e.g., von Hagen and Harden 1995; Alesina and Perotti 1996; Ferejohn 1999; Alt et al. 2002; and Alt and Dreyer Lassen 2006).

A crucial requirement fostering transparency is for governments to inform the legislature and the citizens about all relevant financial aspects of government activity by issuing 
financial reports. However, government agents have strong incentives to influence financial reporting in order to try to improve their electoral prospects. Besides the current evidence for the case of Greece, which systematically manipulated financial information in order to meet European Monetary Union criteria there is ample evidence for 'creative accounting' and misreporting (e.g., Milesi-Ferretti 2004; von Hagen and Wolff 2004 and Wallack 2007) and hence, an independent review of the financial statements is crucial. Such a review of financial statements is conducted by public auditing institutions.

The few economic research contributions on public auditing so far emphasize the important functions of auditors in controlling the government and the bureaucracy by providing information to policymakers and citizens, and in exposing waste and corruption (e.g., Frey 1994; Olken 2007; Ferraz and Finan 2008). The studies by Olken (2007) and Ferraz and Finan (2008) do not primarily focus on the effect of independent audits, but provide, nevertheless, interesting insights for our purposes. Olken (2007) analyzes different methods of reducing corruption using a randomized field experiment in Indonesia. He finds that a greater audit probability significantly reduces wasteful expenditure. Ferraz and Finan (2008) show in a randomized field experiment in Brazil that independent audits actually improve the quantity and quality of information available to the principal, which finally influences voting behavior. These two studies focus only on financial audits. However, some auditing institutions also conduct various forms of performance audits. In a study analyzing US state auditors Schelker (2008) finds evidence that performance audits improve policy outcomes. According to Schelker and Eichenberger (2003), Eichenberger and Schelker (2007) and Schelker (2008) extending the audit mandate even further to include not only standard ex post audits, but also ex ante audits of the budget draft and individual policy proposals lead to significantly lower taxes and expenditures.

Audits are effective only if the auditor has real incentives to reveal inconsistencies and cannot be sanctioned by the audited agent for doing so. Taking the principal-agent relation as a starting point, Tirole (1986) discusses a framework in which a principal hires a supervisor to control the agent. In this three-tier principal-agent model of the principal, the supervisor and the agent, the main problem arises if the supervisor and the agent collude. If the principal is naïve and does not anticipate such collusion, he could be even worse off than without hiring a supervisor (Antle 1984). In such a setting the principal wants to implement contracts that do not provide incentives for collusion between the agent and the supervisor. Models from contract theory assume that the principal himself writes contracts with the agent as well as with the supervisor/auditor and that he tries to implement collusion-proof contracts (see e.g., Tirole 1986; Baiman et al. 1991; Bolton and Dewatripont 2005; and Khalil and Lawarée 2006). This literature shows that collusion of auditor and agent is a serious concern. A first step towards reducing the risk of collusion is to keep the auditor institutionally independent from government agents, most notably from the executive, eliminating direct channels for side-payments and reciprocal behavior. Hence, auditor independence is crucial in order to strengthen incentives for exposing unlawful accounting practices or wasteful policy implementation. Auditor independence is likely to be influenced by the appointing and removal procedures (e.g., Schelker 2008) and the term length and limits on it. The available empirical evidence on auditor appointing and removal procedures is ambivalent and not conclusive yet.

The literature on the role of auditors is much more extensive for the corporate sector. Corporate auditors are assigned to review financial statements, which is crucial for investors and other stakeholders of a firm. From the previous discussion it seems obvious that auditors evaluating financial statements should be independent from the firm's management, which is the direct source of such information. However, the lack of auditor independence 
is one of the major issues in the recent history of corporate governance scandals (e.g., Enron, Tyco, Worldcom and Parmalat). In order to provide an unbiased and impartial view on financial statements, legal provisions usually require that financial reports are audited by an external professional body. However, independence is not guaranteed by the requirement that the auditor must come from an outside company. There are numerous additional threats to auditor independence, starting with the entanglement of audit and non-audit services provided by accounting firms to the same client, appointing and removal procedures, as well as psychological ties to the appointing body. ${ }^{1}$

\subsection{Evidence on term length and term limits}

Term length and term limits crucially impact an agent's incentives. In the public sector this has been analyzed before. However, such studies focused mainly on executive and legislative mandates and did not include auditing institutions. In the literature on term length two advantages of short terms have been advanced: It enables principals quickly to replace poorly performing office holders, and the disciplining effect of frequent electoral pressure should improve accountability and the incentive for the agents to keep close to voters' preferences (Barro 1973 and Ferejohn 1986). In contrast to these arguments a recent contribution by Dal Bo and Rossi (2008) points out that short terms lead to distortions since frequent elections are costly to conduct, could distract politicians and citizens from productive activities, and the short time horizon of officeholders could lead to inefficient investments. In a natural experiment in Argentina Dal Bo and Rossi (2008) scrutinize empirically this ambiguous question of whether shorter or longer terms seem to be more adequate in legislative institutions. The authors exploit random variation in term length for members in the Argentinean legislature in 1983, where half of the representatives were randomly assigned two-year terms and the other half were assigned four-year terms. The authors also study a second natural experiment in the same legislature in 2001. Their overall finding is that the four-year terms seem to induce better performance of legislators relative to the shorter two-year terms. They attribute their results to an investment effect. Longer terms induce representatives to work harder. Since the benefits of investments often do not occur instantaneously, but only in some future period, longer time horizons allow politicians to invest more strongly in political effort. They find evidence supporting their investment logic as opposed to the more traditional accountability argument. This study only compares two-year to four-year and to some extent six-year terms and it remains unclear if these positive effects dominate even for longer terms, since it is possible that at some point the accountability effect dominates the investment effect. $^{2}$

\footnotetext{
${ }^{1}$ For further details on appointing and removal procedures in the corporate sector see e.g., Acemoglu and Gietzmann (1997), Mayhew and Pike (2004), and Davidson III et al. (2006). Schelker and Eichenberger (2003), Bebchuk (2007) and Benz and Frey (2007), who recommend the direct election of the corporate auditor by shareholders. In a series of experiments with professional auditors Bazerman et al. (2002) show that individuals evaluate the same facts systematically differently if tied (e.g., hired) to different bodies. Individuals do not even need to have strong ties to some party. In order to observe such bias it is sufficient that they are loosely connected (e.g., a hypothetical professional relationship is sufficient).

${ }^{2}$ A similar randomized study by Titiunik (2008) on the influence of term length on productivity in US state senates finds that shorter terms increase abstention rates and reduce the number of bills introduced in the legislature. The direction of these results can be interpreted in line with Dal Bo and Rossi (2008).
} 
Similar evidence exists from studies on the influence of corporate auditor tenure on audit quality. ${ }^{3}$ At the core of this discussion is the trade-off between improving auditor independence and accountability, and the associated costs of forgoing auditor expertise. Proponents of short auditor terms and mandatory rotation requirements (which is similar to a term limit) argue that these factors improve independence because managers cannot directly threaten auditors with dismissal and cannot promise future income due to reappointment. ${ }^{4}$ Opponents point out that short terms and mandatory rotation of the corporate auditor involves a loss of expertise because the new auditor does not know the company well and must first acquire the relevant company- and industry-specific know-how. This lack of expertise and the lack of incentives to invest in firm-specific knowledge due to the short period during which auditors can expect returns from such specific investments may lead to increased audit failure. Such failure worsens the agency problem and weakens credibility of financial statements.

Many countries have adopted term limits for elective offices in recent years. Testing a political agency model Besley and Case (1995) show that US state governors subject to a binding term limit implement systematically different fiscal policies than governors who can stand for re-election. They suggest that governors eligible to run again care about reputation building and, hence, adjust economic policy choices to this constraint. In states with binding term limits they find fiscal cycles with higher taxes and expenditure in the last term if the governor is a Democrat. ${ }^{5}$ However, the discussion on the long term effects of term limits suggests that they might reduce entrenchment effects, due to the accumulation of political capital that undermines electoral discipline for long-lived incumbents (Besley and Case 1995). The general question is why voters should be in favor of term limits since they cannot retain good policymakers in office and cannot threaten a term limited official to be replaced with a challenger should he not perform well, e.g., induce inefficient fiscal cycles. Moreover, term limits reduce the value of being in office and might reduce the willingness to invest in welfare improving longer term projects. Motivated by the observation that voters regularly support the introduction of term limits Smart and Sturm (2006) analyze theoretically the influence of the existence of binding term limitations. ${ }^{6}$ They in turn argue that term limits reduce the value of holding office which encourages politicians to implement policies that are closer to their private preferences. Such behavior can be welfare improving from a voter's perspective, if typical policymakers usually do not adopt policies that are unpopular at the time of the decision, but welfare improving in the future. Such a mechanism suggests that term limits make it possible for policymakers to actually implement welfare improving

\footnotetext{
${ }^{3}$ Note that this discussion focuses on actual tenure and not official term length. Recent contributions are e.g., Dopuch et al. (2001), Gietzmann and Sen (2002), Johnson et al. (2002), Myers et al. (2003), Mansi et al. (2004), Comunale and Sexton (2005), and Gosh and Moon (2005).

${ }^{4}$ Furthermore, it is often suggested that extended client-auditor relationships alone impede on auditor independence due to evolving ties between auditor and client (e.g., Mautz and Sharaf 1961).This argument is underlined by psychological evidence showing that with closer ties between client and auditor psychological bias grows stronger (Bazerman et al. 2002). Moreover, 'low-balling' is also constrained by shorter terms and rotation requirements. 'Low-balling' refers to audit firms offering fees that are lower than the marginal costs of the initial engagement with a new client. Such an offer is interesting if the audit firm anticipates declining marginal costs of future audits if it is rehired (Dopuch et al. 2001).

${ }^{5}$ Johnson and Crain (2004) extend this analysis to investigate the influence of term limits on fiscal policy in a cross-country setting.

${ }^{6}$ See Lopez (2003) for a summary and evaluation of the economic rationales of term limit implementation, and Franklin and Westin (1998) for a theoretical model predicting seniority turnover and transition consequences of term limit reforms.
} 
long term projects, the costs of which are visible today but result in benefits only in the future. Various authors discuss further distortions that can be alleviated by implementing term limits. Dick and Lott (1993) and Buchanan and Congleton (1994), for example, argue that the ability of a politician to transfer resources to his electoral district increases over time in office, which gives him an advantage relative to other representatives. At the aggregate level such behavior leads to reduced government efficiency. An alternative explanation is based on a well-documented incumbency advantage, suggesting that term limits have a positive effect since they limit the influence of incumbency advantages (Glaeser 1997). Daniel and Lott (1997) show that the introduction of legislative term limits in California dramatically reduced campaign expenditures and increased electoral competition. They attribute these effects to the reduced returns to a political career, which makes it more interesting for new candidates to enter electoral races since campaign expenditures and incumbency advantages are being lower. For a more extensive discussion of the available literature see Lopez (2003) and Smart and Sturm (2006).

The evidence on official term length suggests that very short terms do not seem to be favorable and that longer terms induce policymakers to invest more in political effort. ${ }^{7} \mathrm{How}-$ ever, it is unclear if even longer terms would be beneficial or if the positive effects vanish due to the reduced accountability induced by less frequent electoral pressure. Hence, one could imagine a non-linear relationship, in which very short and very long terms diminish the performance of elected officials. The effects of term limits seem to be controversial as well, since there are theoretical arguments that speak for as well as against term limits.

\subsection{Auditor term length and term limits}

Public auditing institutions typically include a chief auditor and a whole structure of departments with auditing and administrative staff. The chief auditor is responsible for the overall activity of the office. Several units specialize in the various audits conducted. The chief auditor could be compared to the lead partner of a big auditing firm, who is responsible for advising in formulating policy and for carrying out the audit mandate but is not necessarily directly working in the actual audit process. He defines the audit policy and audit strategy and he typically enjoys a high degree of autonomy within the legal and regulatory framework. He can usually influence what is the subject of the current audit, its timing, priorities and the degree of thoroughness, which are essential for the understanding of his role as supervisor of bureaucratic agencies in a principal-agent framework.

Generally auditors are appointed by the legislative or the executive branch and only in a few cases-such as some US state auditors and local auditors in Switzerland-auditors are elected directly by the citizens. For the purpose of this analysis it is important to note that auditors are subject to a regular evaluation mechanism by either the legislative, the chief executive, or the citizens. Consequently, there is an accountability mechanism at work which takes effect at predetermined intervals. ${ }^{8}$ It is certainly true that there is an important difference between auditor and legislative or executive mandates since auditors are not involved in actual policy making. They have a clearly defined audit mission that is regulated by standardized procedures. Such procedures do not provide as much leeway as is granted

\footnotetext{
${ }^{7}$ Dal Bo and Rossi (2008) measure political effort as a legislators activity in terms of attendance to floor sessions, number of floor speeches, participation in the production of committee bills, the number of bills each member introduced, and how many of these became law.

${ }^{8}$ For a theoretical discussion of the influence of accountability mechanisms in the public sector see Maskin and Tirole (2004).
} 
to public officials endowed with decision-making power over the provision of public goods. Nevertheless, auditors face a similar incentive structure since they enjoy important degrees of freedom in determining the timing and thoroughness of audits, which are crucial factors in the audit process.

The theoretical discussion above reveals two basic effects: on the one hand, there is an accountability mechanism at work. On the other hand, auditors have to invest in office-specific expertise in order to become effective supervisors, which is less attractive for shorter office terms. Both the accountability and investment arguments are also important for public auditors. Even though the trade-off between accountability and investment seems to be similar, the optimal term length might be very different than those of legislators or the chief executive. The impact of term limits was described as being ambiguous. On the one hand, a binding term limit might induce auditors not to keep up with new developments and reduce specific investments in expertise due to their compressed time horizon, and they might provide incentives to conceal audit specifics to the next auditor. On the other hand, a binding term limit might induce incentives to be even more rigorous and disclose information that would reduce the chances of being reappointed. ${ }^{9}$

\subsection{Auditors and fiscal outcomes}

From an economic perspective the pertinent research question is how auditor characteristics shape public sector performance. This is important both for citizens and financial market participants investing in public debt. Electoral decisions by voters and reactions by investors in financial markets require credible information on the state of public finance. As discussed above more stringent audits enable principals to better control government agents or make more appropriate investment decisions, because they can observe a more reliable signal about the state of public finances. Direct links between audited information and fiscal and electoral outcomes have been established in the papers by Olken (2007), who finds that independent government audits reduce wasteful spending, and Ferraz and Finan (2008), who find lower electoral chances for corrupt mayors that have been audited prior to elections. The cited literature on transparency in the fiscal process also relates transparency measures to fiscal outcome variables such as deficits and debt accumulation.

Analyzing the relevant effect of auditor terms and term limits on public sector performance presents some important challenges for empirical research. Since the quality of fiscal data itself depends on audit quality, fiscal variables such as expenditures, revenues, deficits, or debts are not appropriate as dependent variables (see Schelker 2008). In other words, data quality is endogenous to auditor characteristics, which undermines statistical inference. A research question focusing on the influence of institutional characteristics on audit thoroughness and audit quality can therefore not rely on reported fiscal measures. It is likely that this problem also affects other studies relying on fiscal data as dependent variables to analyze the influence of fiscal institutions enhancing transparency. Moreover, there are further problems directly linked to fiscal data. Most importantly, the absolute levels of fiscal measures are not necessarily informative about government performance since efficient governance

\footnotetext{
${ }^{9}$ Note that the paper focuses on official auditor term length and not on actual auditor tenure since auditor tenure is endogenous to many different factors, such as official term length, term limits, appointing and removal procedures, collusive behavior of the auditor with the agent etc. Empirically it would be extremely challenging to disentangle all these effects. Therefore, the theory and the empirical evidence focus on the effects of official term length and term limits, which are institutionally determined factors and not direct outcome variables. Term length regulations create different incentives while the regulation itself has been in place for a long time and should not be a direct outcome variable.
} 
can involve higher or lower levels of e.g., expenditures, deficits or debts, depending on the state of the economy and the characteristics and quality of the financed public goods (e.g., Eichenberger 1994; Ferejohn 1999; Alt et al. 2002 and Schelker 2008). Therefore, for example, the level of accumulated debt is not necessarily indicative of the state of public finance and credit worthiness. The quality of the investments made may vary considerably, which impacts on public finance and the need for future tax hikes and thus, on a state's ability to repay its debts. From this perspective it seems natural to adopt long term state credit ratings. These measures have several advantages. State credit ratings reflect a market evaluation of state fiscal performance. They are forward looking evaluations of the creditworthiness of the borrower taking into account the credit history, accumulated debt, the actual state of public finance as well as the local economy, and public governance (e.g., Capeci 1991 and Johnson and Kriz 2005). A further advantage is that pure fiscal level effects and data quality effects can be controlled for by including fiscal measures such as debt or expenditure levels into the regression framework.

\subsection{Hypothesis}

From the theoretical discussion it is not entirely clear if shorter or longer terms are more favorable. The influence of auditor term length on credit ratings might follow a non-linear pattern. Very short as well as very long auditor-agent relationships seem to be unfavorable from a theoretical perspective. It is likely that auditor performance is weak in the beginning and for short terms due to the lack of expertise and the weak incentives to exert effort; then with longer terms, auditor performance increases due to stronger incentives to exert effort, invest in knowhow and learning; and then decreases with even longer terms due to dwindling accountability. Therefore, I also examine if there are non-linear (quadratic) effects of auditor terms on credit ratings. Theoretical considerations on the impact of term limits do not provide a clear-cut hypothesis either. There are arguments that speak in favor of, as well as against term limits. It is mainly an empirical question to determine the influence of auditor term length and term limits on government performance.

In the empirical section I estimate the following basic equations:

$$
\begin{aligned}
& y=\alpha+\beta \text { term length }+\gamma \text { term limit }+\zeta \boldsymbol{A}+\lambda \boldsymbol{X}+\varepsilon \\
& y=\alpha+\beta_{1} \text { term length }+\beta_{2}(\text { term length })^{2}+\gamma \text { term limit }+\zeta \boldsymbol{A}+\lambda \boldsymbol{X}+\varepsilon
\end{aligned}
$$

where $y$ is the state credit rating, the variables term length and (term length $)^{2}$ indicate auditor term length in years and the squared value respectively and term limit is a dummy variable that equals 1 if a term limit is enacted. $\zeta$ and $\lambda$ are parameter vectors, $\boldsymbol{A}$ is a matrix capturing additional features of the various auditing offices, $\boldsymbol{X}$ is a matrix including additional cross-section characteristics, and $\varepsilon$ is, of course, the error term.

\section{Empirical evidence from US state auditing institutions}

\subsection{US state auditors}

In order to analyze the influence of auditor terms and term limits I take advantage of the decentralized US federal structure. The US states enjoy a high degree of autonomy and every state has its own constitution that defines the primary governance structures and processes. The main advantage in this setting is that the states feature different regulations concerning 
the institutional details of their auditing institution. Variation can be observed on various dimensions, notably in the term length and term limit requirements as well as in appointing and removal procedures. US state auditors are either elected by the citizens, or appointed by the legislative, or in very rare cases by the executive branch. In the case of elected or legislatively appointed auditors the agent (executive) can neither directly select the auditor, nor influence it by promising future appointment.

The focus of the empirical analysis is on the influence of auditor term length and term limits on public sector performance measured by General Obligation Bond ratings. In most US states auditors are not appointed to open terms in office, but for a fixed term that varies in length across states. Most commonly state laws define a fixed term length $(2,4,5,6,7$, 8 , or 10 years) after which the auditor-principal relationship ends. Some states allow their auditors to reapply for the position and some states impose a binding term limit.

\subsection{The data}

In order to conduct the empirical analysis I adopt a unique dataset containing information on a variety of institutional details of US state auditing institutions stemming from information gathered by NASACT, the National Association of State Auditors and Comptrollers and Treasurers (see Table 5 in the Appendix and Schelker 2008). In addition to the information on various characteristics of the US state audit offices, the dataset contains a whole range of state-specific standard control variables (see Alt et al. 2006 and Besley and Case 2003) ranging from information on fiscal performance, state fiscal institutions such as balanced budget requirements (e.g., Bohn and Inman 1996; Poterba 1994, 1996; Poterba and Rueben 2001 and Johnson and Kriz 2005), voter initiatives (e.g., Matsusaka 2004), fiscal transparency (e.g., von Hagen and Harden 1995; Alesina and Perotti 1996; Ferejohn 1999; Alt et al. 2002 and Alt and Dreyer Lassen 2006), to population and income data. The panel dataset contains state-specific information between 1990 and 1999. More details and summary statistics for the main variables can be found in Table 6 in the Appendix.

Since officially reported fiscal variables are not appropriate, I adopt state General Obligation Bond (GOB) ratings that reflect a market evaluation of state fiscal performance. Johnson and Kriz (2005) and Depken and Lafountain (2006) use a similar approach to estimate the impact of fiscal institutions and state corruption respectively on state credit ratings. Johnson and Kriz (2005) find that the existence of balanced budget requirements and debt and expenditure limitations are significantly correlated with higher state credit ratings. Depken and Lafountain (2006) find that more corruption is correlated significantly with lower credit ratings. The results for similar control variables in the present study are consistent with the findings reported in Johnson and Kriz (2005) and Depken and Lafountain (2006). ${ }^{10}$ In the literature on the influence of auditor tenure in the corporate sector similar approaches using corporate credit ratings have been implemented (e.g., Mansi et al. 2004). In order to obtain the market evaluation of anticipated audit quality I always control for the influence of the

\footnotetext{
${ }^{10}$ Further studies assessing borrowing cost use credit ratings as explanatory variables (e.g., Benson et al. 1986 and Benson and Marks 2007) and find that other factors beyond credit ratings also impact on borrowing cost. Capeci (1991) reassesses the findings of Benson et al. (1986) and disentangles market assessments of credit worthiness from direct effects of credit ratings. He finds that borrowing rates and credit ratings closely respond to fiscal indicators, which is consistent with the view that credit markets discipline municipal fiscal behavior. Hence, credit ratings seem to be strong, though probably not perfect proxies for state fiscal performance.
} 
reported state of public finance and hence, I include real per capita state debt accumulation as a covariate in the regression framework. ${ }^{11}$

The data on state credit ratings are collected from Moody's Investor Services, Fitch Ratings and Standard \& Poor's. State General Obligation Bond ratings are available for a maximum of 42 US states for some or the entire period 1990-1999, but do not include states that have no general obligation debt. ${ }^{12}$ When observing states without General Obligation Bond (GOB) ratings, selection bias seems a concern. When approaching this potential selection problem, I do not find a significant correlation between auditor characteristics and the excluded states. Furthermore, I cannot explain any of this selection with the auditor or institutional variables in a regression framework either. Hence, it seems that selection bias is not a major concern for the study. In the context of this study a further, though minor, adjustment is the exclusion of Alaska and Hawaii from the analysis, which is the general practice for studies analyzing fiscal institutions in US states (see e.g., Alt et al. 2002). Alaska and Hawaii are outliers in many respects, but most importantly with regard to fiscal data, since these states depend disproportionally on federal transfers. Given the available data, the exclusion of Alaska and Hawaii does not affect the results associated with auditor term and term limits in the present study, while it enables the readers to compare the results to related work using fiscal data at the US state level.

The construction of the credit rating variable follows the approach suggested by Depken and Lafountain (2006). The three principal rating agencies (Moody's, Standard \& Poor's, and Fitch) rate state General Obligation Bonds. Unfortunately, it was not possible for this study to collect Standard \& Poor's (S\&P) ratings prior to $1995 .{ }^{13}$ Hence, the ratings from 1990 to 1994 have to rely on ratings provided by Moody's and Fitch. The agencies use very similar rating scales. S\&P and Fitch use a rating scheme that ranges from AAA to D including 22 rating categories, while Moody's rates GOBs according to a rating ranging from AAA to $\mathrm{C}$ with 21 categories. In order to construct a single credit rating measure including all available rating information I first assign every rating category a score between -1 and -21 in the case of Moody's and -22 in the case of Fitch and S\&P. Following the notation by Depken and Lafountain (2006) the numerical rating for state $s$ in year $t$ by rating agency $j$ is $R_{s t j} \in\left\{-1, \ldots,-N_{j}\right\}$, where -1 corresponds to the highest GOB rating and $-N_{j}$ the lowest GOB rating by agency $j .{ }^{14}$ In a second step I normalize these scores $R_{s t j}$ by dividing them by the number of possible ratings $N_{j}$ for each rating agency $j$ $\left(R_{s t j}^{\prime}=R_{s t j} / N_{j}\right)$. In a last step I average the available normalized rating scores $R_{s t j}^{\prime}$ to obtain a normalized overall rating $R_{s t}^{\prime}$ for each state $s$ in year $t$. Since not all state GOBs are always rated by all three rating agencies, some state rating measures rely on only two or in some cases one agency. This, however, is the case for a minority of all states and years, but could not be circumvented.

\footnotetext{
${ }^{11}$ The results are not sensitive to other fiscal control variables such as per capita tax collection, general government revenues and expenditures. Also including all measures at once does not invalidate my results; however, the estimated effect of the different fiscal variables become unstable since these measures are highly correlated.

${ }^{12}$ The states without any rating during the analyzed period are Arizona, Colorado, Iowa, Idaho, Nebraska and South Dakota.

${ }^{13}$ Moody's Investor Services and Fitch Ratings provided the data used in this study directly. The S\&P ratings could not be received from S\&P. However, S\&P rating information could be gathered from the US Census Bureau from 1995-1999.

${ }^{14}$ According to this scale the ratings are categorized as follows: AAA $=-1$ to $\mathrm{C}=-21$ (lowest rating for Moody's) and $\mathrm{D}=-22$ (S\&P and Fitch). The negative signs serve only the purpose of making it easier and more intuitive for the reader to interpret the regression results.
} 


\subsection{The empirical strategy}

I present the results in two parts: First, I run a series of regressions analyzing the linear influence of auditor term length and term limits on credit ratings, and in a second part I examine the discussed potential non-linear relationship of term length on outcomes and present the same series of regressions including the squared of the term length variable to account for non-linear effects of auditor terms.

As I proceed with reporting the results of the empirical analysis, I always start with estimating a linear model that abstracts from the fact that the dependent variable is censored. These linear models are typically good approximations and the interpretation of the effects is straightforward. In a next step I take the specific characteristics of the normalization of the dependent variable into account. The normalized variable varies between -1 and 0 . Therefore, I estimate Tobit regression models. ${ }^{15}$ The OLS and Tobit models assume that the variance of the cross-section specific effects $\left(a_{i}\right)$ is zero $\left(\operatorname{var}\left(a_{i}\right)=0\right)$. In the present setting such an assumption is likely to be violated. In order to relax this assumption, I estimate random effects (RE) models that assume that the $a_{i}$ 's result from a random draw and follow a normal distribution. I conduct Lagrange multiplier tests which indicate that $\operatorname{var}\left(a_{i}\right) \neq 0$ and hence, the random effects estimates allowing for individual heterogeneity are the preferred specification and will be presented in the following tables. Due to the time persistence of the main explanatory variables I am not able to further relax the assumption and it is not possible to estimate fixed effects models allowing for arbitrary correlation between $a_{i}$ and the explanatory variables, i.e., I cannot control for unobserved time-invariant heterogeneity.

Since the audit offices differ along various dimensions, I control for effects resulting from the different auditor selection and removal mechanisms and for differences in the audit mandate. ${ }^{16}$ Furthermore, all regressions include real per capita state debt, and a range of standard covariates controlling for state-specific heterogeneity. This is important in order to take structural differences between the states into account. I always start by presenting a basic regression model only including the most standard control variables (real per capita income, population size, unemployment rate, fraction of young and aged population, and a dummy for southern states) and then present further specifications controlling for time effects and additional covariates that have proven to be influential in previous research at the US state level (population density, strict balanced budget law (no carry-over rule), initiative rights). Likelihood ratio tests show that the regression model including the time effects fit the data significantly better than the basic model without time effects. Therefore, all regressions beyond the basic regression model include year fixed effects, but I continue to report the basic regression for comparison in all tables. The third regression includes a dummy variable controlling for whether the auditor serves a predetermined fixed term length as opposed to an open mandate, which has been coded as a term length of zero years. This coding reflects the fact that auditors without a predetermined term length (open mandate) serve at the pleasure of the appointing body. Coding it as zero might be subject to discussion. Therefore, I control

\footnotetext{
${ }^{15}$ When using non-normalized credit rating data the dependent variable is of ordinal scale. Therefore, I also estimated ordered probit models. The results are not sensitive to this model variation. All regression results including ordered probit and random effects ordered probit estimates can be found in Schelker 2009. The random effects ordered probit models have been calculated by applying the estimation procedures proposed by Frechette (2001a, 2001b) using Gauss-Hermite quadrature.

${ }^{16}$ Not all states require the auditor to conduct exactly the same types of audit. In addition to standard financial audits several state auditors also conduct performance audits. Financial audits follow standard accounting rules and are comparable across states. The differences in the extent to which performance audits are conducted are controlled for in the empirical model.
} 
for these cases in the third and fourth regressions and additionally present separate tables for a subsample of states in which the auditor serves a fixed term. This procedure is applied for both econometric model classes, the linear random effects models and the random effects Tobit models.

\subsection{Empirical results}

Tables 1 to 4 present the regression results of auditor terms and term limits on state GOB ratings. The empirical analysis starts with a first part estimating the influence of term length and term limits on GOB ratings (Tables 1 and 2). In a second part the analysis proceeds by incorporating the squared value of the term length variable into the regression framework (Tables 3 and 4) in order to assess potential non-linear effects.

Note that the empirical results do not allow a causal interpretation of the influence of auditor characteristics on credit ratings, since I cannot exclude endogeneity of the auditor characteristics. Unfortunately, along with other studies on fiscal institutions (e.g., Poterba 1994; Poterba and Rueben 2001; Johnson and Kriz 2005 and Depken and Lafountain 2006) I could not find valid instruments allowing me to establish causal relationships. Since the present institutional frameworks remained stable over time reverse causality should not be a major concern. However, simultaneity and omitted variable bias still undermine causal inference. In order to reduce such bias a whole set of control variables is included. Table 1 shows the estimation results when all control variables are entered. It can be seen that the results are in line with previous research using the same or similar covariates. For this reason and for the sake of legibility and clarity the estimation results of control variables will be omitted in the subsequent Tables 2 to 4.

Columns 1 to 4 of Table 1 summarize the linear random effects estimates while columns 5 to 8 present the random effects Tobit estimates. Both estimation procedures yield very similar results in terms of coefficient magnitude and statistical significance.

Columns 1 and 5 of Table 1 show the basic regression estimates including the two main variables of interest-term length and term limits - and a basic set of control variables. In the basic regression models in columns 1 and 5 the influence of term length is significantly estimated for both regression procedures. Including time fixed effects in columns 2 and 6 improves the model's fit (likelihood ratio tests not reported) and hence, they are included in all follow-up regressions. The estimated coefficient of term length is again negative and remains statistically significant when adding time fixed effects to the base regression. In columns 3 and 7 a dummy for auditors with a fixed term is included. With this procedure I control for structural differences that might exist between auditors with an open mandatei.e., who serve at the pleasure of the appointing body-and auditors with a predetermined fixed term length - e.g., four years with the possibility of renewing the appointment. Moreover, this mitigates possible concerns about the coding of the term length of auditors with an open mandate. These concerns are further addressed by a series of regressions focusing entirely on a sub-sample of states excluding auditors serving an open mandate (see Tables 2 and 4). In this setup the estimated coefficient of the term length variable becomes insignificant. The estimated coefficient reacts fairly sensitively to the inclusion of the dummy variable for auditors with a fixed mandate. The inclusion of further control variables that proved to be important in previous research at the US state level (population density, strict balanced budget rule, and voter initiatives) has no further impact on the estimated coefficients of the term length variable. Overall, the estimated coefficients are mostly negative but not robust to changes in model specification.

The influence of auditor term limits is positive and statistically highly significant across all estimated models and specifications. The coefficient is fairly robust to changes in model 


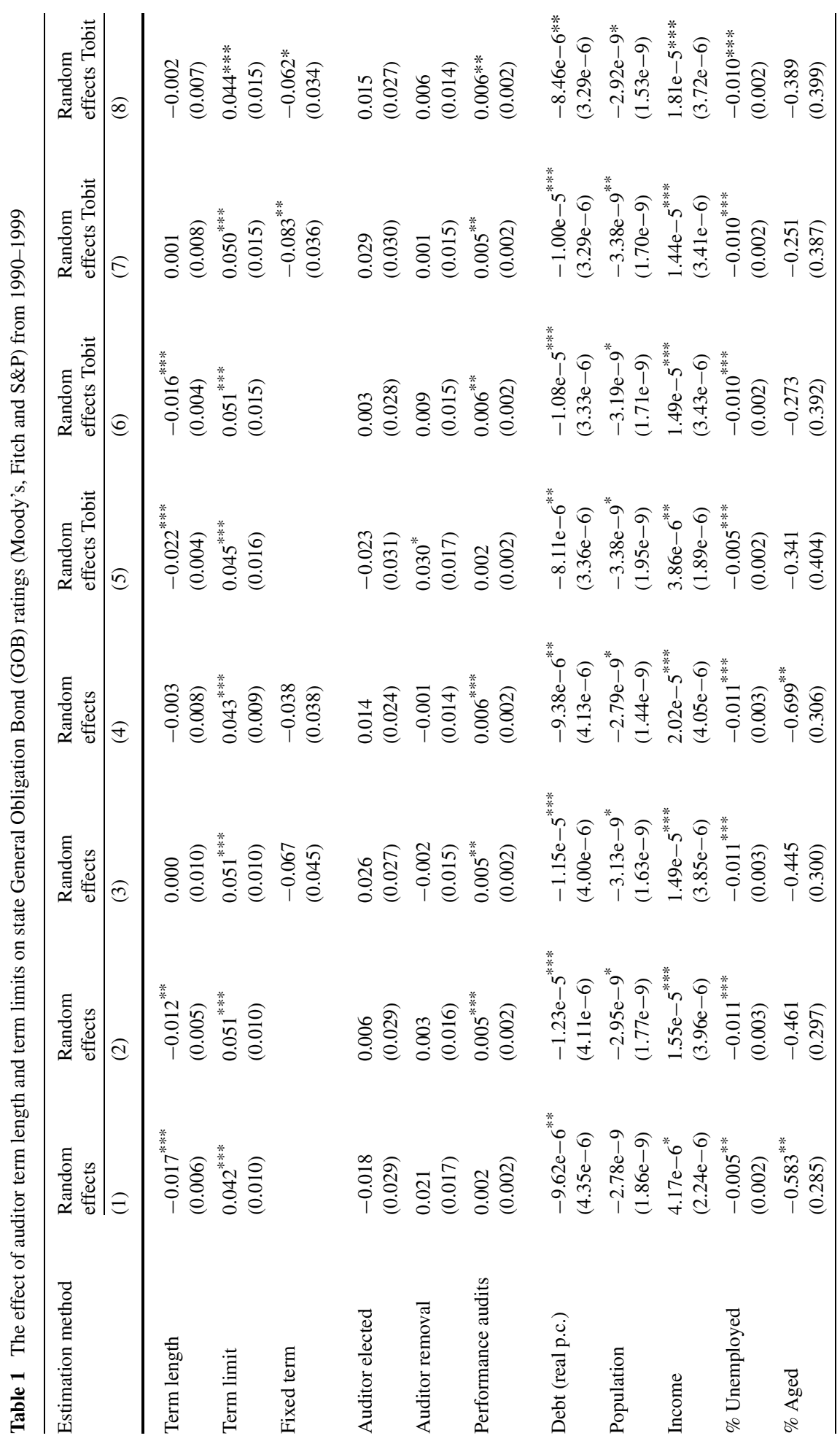




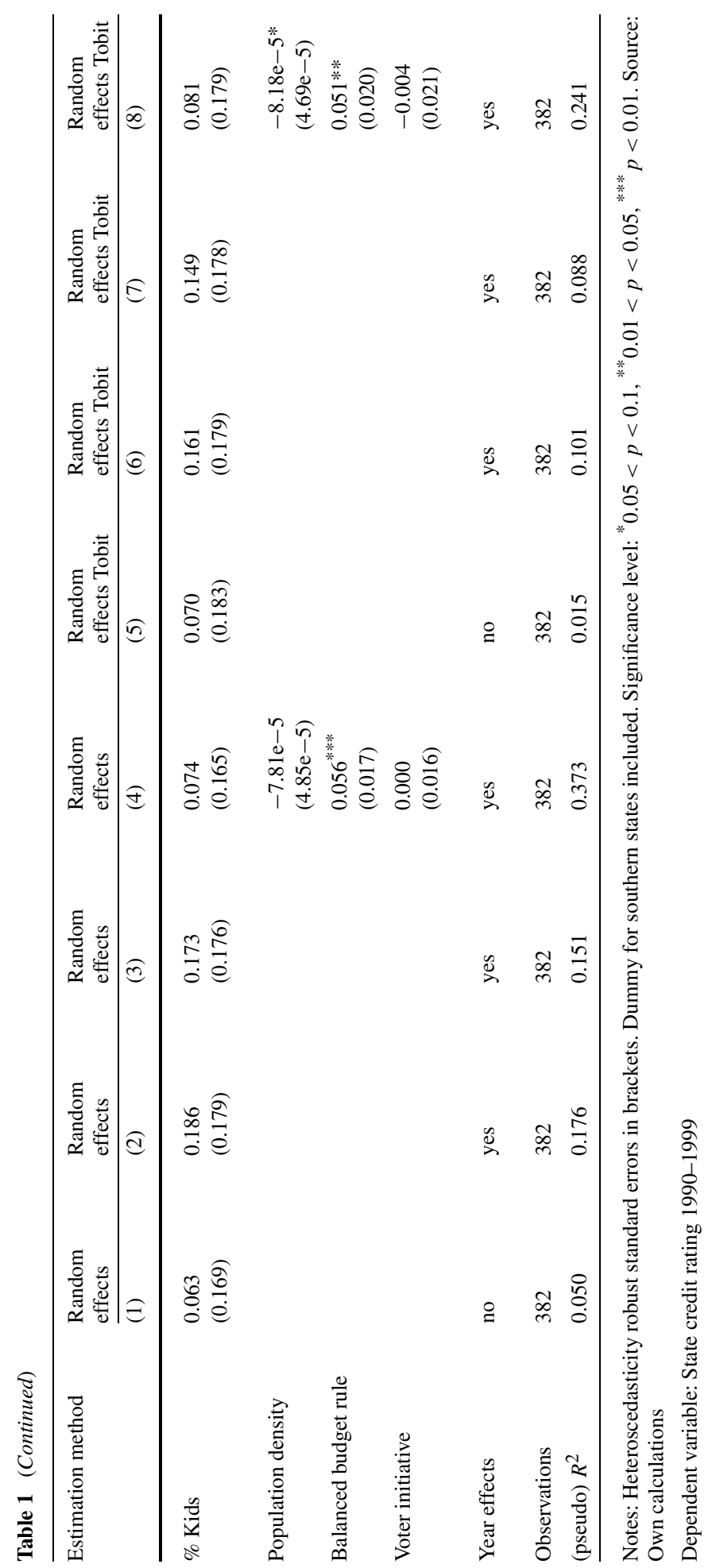


specifications and the choice of the estimation method. Hence, if a term limit constrains auditor tenure I find significantly higher credit ratings. The magnitude of the effect is on average a roughly 0.8 to 1 notch higher credit rating for states in which the auditor faces a term limit (e.g., from AA to AA+).

It might be a concern that the auditor term limit is just a mirror of a more general practice in a state to limit office terms. When investigating this concern, I find that the correlation of auditor term limits with term limits for the state governor is low (0.194) and the auditor term limit estimates are not affected at all by the inclusion of a measure accounting for governor term limits. The coefficient of auditor term limits remains positive and significant with values close to the ones reported in the tables, while the influence of governor term limits is negative and significant in only some specifications.

The inclusion of the fixed term variable largely does not yield conclusive results. The auditor election and removal procedure variables yield no clear results either. This is in line with Schelker (2008) who finds that the audit mandate plays an important role for answering the question whether auditors should be appointed or elected. The empirical findings provide weak evidence for an interaction effect between the appointment mechanism and the audit mandate. The argument follows Ferejohn (1999) and Maskin and Tirole (2004) who argue that appointment of a bureaucrat is desirable in the case of very technical tasks, where the electorate is poorly informed about the optimal action, while the direct election of an accountable agent is due in cases related to public goods provision. From this perspective public auditors with the exclusive mandate to conduct financial audits should rather be appointed than elected. Such audits have no direct public goods component and are very much a technical issue. In contrast, auditors with a strong mandate to conduct performance audits also target public goods provision in which the legislative is involved.

The variable capturing the audit mandate to conduct performance audits mostly produces statistically significant results. States which impose stronger mandates to conduct performance audits tend to be associated with higher credit ratings. All further included control variables follow the expected patterns, and are in line with previous research. The real per capita state debt variable is consistently negative and significant. This is according to the general expectation that a larger public debt reduces credit worthiness and thus, reduces credit ratings. Higher real per capita income significantly improves ratings, while higher unemployment rates reduce credit ratings. The fraction of the young and aged population often do not impact on credit ratings significantly. The population variables (size and density) are negatively correlated with credit ratings which points to diseconomies of scale. To put these results in perspective it is important to note that the literature is ambiguous with respect to these questions. Estimating population effects at such an aggregated level might not be representative for all classes of jurisdictions and the optimal size of jurisdictions depends on the context and the analyzed dimension. The strict balanced budget requirements (no carry-over rule) are positively and significantly correlated with credit ratings and confirm the disciplining effect of strict balanced budget rules as is established in the literature (e.g., Bohn and Inman 1996; Poterba 1994, 1996 and Johnson and Kriz 2005). The right to bring forward citizen initiatives is mostly positively correlated with credit ratings; however, the effect is usually not statistically significant.

When restricting the analysis solely to include states with a fixes auditor term, and thus, leaving aside all states in which the auditor serves at the pleasure of the appointing body, the sample shrinks to 29 states over the same time period, leaving us with 258 observations. Restricting the sample is a way to assess the robustness of the previous results. The estimates in Table 2 are presented in a similar way as in Table 1, but omitting the presentation of coefficient estimates for the control variables. Columns 1 and 4 report the basic regression 
Table 2 Sub-sample of states with fixed auditor terms: the effect of auditor term length and term limits on state GOB ratings (Moody's, Fitch and S\&P) from 1990-1999

\begin{tabular}{lllllll}
\hline Estimation method & RE & RE & RE & RE-Tobit & RE-Tobit & RE-Tobit \\
\cline { 2 - 7 } & $(1)$ & $(2)$ & $(3)$ & $(4)$ & $(5)$ & $(6)$ \\
\hline Term length & -0.004 & -0.004 & -0.007 & -0.004 & -0.004 & -0.007 \\
Term limit & $(0.008)$ & $(0.008)$ & $(0.008)$ & $(0.005)$ & $(0.005)$ & $(0.004)$ \\
& $0.041^{* * *}$ & $0.052^{* * *}$ & $0.041^{* * *}$ & $0.040^{* * *}$ & $0.051^{* * *}$ & $0.039^{* * *}$ \\
Basic controls & $(0.012)$ & $(0.012)$ & $(0.011)$ & $(0.015)$ & $(0.014)$ & $(0.014)$ \\
Year effects & yes & yes & yes & yes & yes & yes \\
Add. controls & no & yes & yes & no & yes & yes \\
Observations & 258 & no & yes & no & no & yes \\
(pseudo) $R^{2}$ & 0.414 & 0.483 & 0.566 & 0.170 & 0.280 & 0.387 \\
\hline
\end{tabular}

Notes: Heteroscedasticity robust standard errors in brackets. Basic controls: Auditor election, performance audits, auditor removal procedure, real per capita state debt, state population, state income per capita, unemployment rate, fraction of aged, fraction of school-aged, dummy for southern states. Add. controls: population density, balanced budget requirement, voter initiative. Significance level: ${ }^{*} 0.05<p<0.1$, ** $0.01<p<0.05,{ }^{* * *} p<0.01$. Source: Own calculations

Dependent variable: State credit rating 1990-1999

models, Columns 2 and 5 add time fixed effects, and Columns 3 and 6 include the additional controls already presented in Table 1 .

The coefficient of the auditor term length variable is always negative but cannot be estimated with statistical precision. The estimated coefficients of the influence of auditor term limits are robust to changes in the sample size and various model specifications and yield consistently positive and significant results. The additional control variables follow the same patterns as just described.

In Tables 3 and 4 I conduct the same empirical analyses as above but explore potential quadratic effects of auditor term length. Therefore, I add a squared term of the term length variable to all previously reported model specifications.

The estimated coefficients of the squared term length variable in Tables 3 and 4 are not estimated with great precision in the linear random effects models (see columns 1-4 in Table 3 and columns 1-3 in Table 4). Only the random effects Tobit models yield some significant results (see columns 5-6 in Table 3). However, these results are sensitive to the inclusion of the fixed term-length variable and never yield significant effects when focusing on the subsample of states with a predetermined term length in Table 4.

The coefficients of the term length variable reported in Table 3 are-similar to the previous results-negative, indicating lower credit ratings for states that provide for longer auditor terms; however, statistical significance cannot be achieved when controlling for the fixed term-length variable. The estimates in the sub-sample of states with fixed auditor terms (Table 4) do not yield any statistically significant estimates. A meaningful interpretation of the effect of auditor term length and the combined (linear and non-linear) effect of the office term is hence not possible.

The effect of term limits is again consistently estimated and I find a statistically significant and positive correlation between it and credit ratings. The size of the effect is not af- 
Table 3 The effect of auditor term length, term length squared, and term limits on state GOB ratings (Moody's, Fitch and S\&P) from 1990-1999

\begin{tabular}{lllllllll}
\hline $\begin{array}{l}\text { Estimation } \\
\text { method }\end{array}$ & RE & RE & RE & RE & RE-Tobit & RE-Tobit & RE-Tobit & RE-Tobit \\
\cline { 2 - 8 } & $(1)$ & $(2)$ & $(3)$ & $(4)$ & $(5)$ & $(6)$ & $(7)$ & $(8)$ \\
\hline Term length & $-0.034^{* * *}-0.027^{* *}$ & -0.026 & -0.030 & $-0.040^{* * *}$ & $-0.032^{* * *}$ & -0.029 & -0.033 \\
& $(0.012)$ & $(0.011)$ & $(0.029)$ & $(0.024)$ & $(0.008)$ & $(0.008)$ & $(0.030)$ & $(0.027)$ \\
(Term length) & $-2.61 \mathrm{e}-4$ & $-2.38 \mathrm{e}-4$ & $4.62 \mathrm{e}-6$ & $-2.93 \mathrm{e}-4$ & $-2.69 \mathrm{e}-4$ & $5.05 \mathrm{e}-5$ & $-2.61 \mathrm{e}-4$ & $-2.38 \mathrm{e}-4$ \\
& $(0.003)$ & $(0.003)$ & $(0.003)$ & $(0.002)$ & $(0.002)$ & $(0.001)$ & $(0.003)$ & $(0.003)$ \\
Term limit & $0.043^{* * *}$ & $0.052^{* * *}$ & $0.052^{* * *}$ & $0.044^{* * *}$ & $0.045^{* * *}$ & $0.051^{* * *}$ & $0.051^{* * *}$ & $0.045^{* * *}$ \\
& $(0.010)$ & $(0.010)$ & $(0.010)$ & $(0.010)$ & $(0.015)$ & $(0.015)$ & $(0.015)$ & $(0.015)$ \\
Fixed term & & & -0.004 & 0.027 & & & -0.008 & 0.015 \\
& & & $(0.065)$ & $(0.055)$ & & & $(0.079)$ & $(0.072)$ \\
Basic controls & yes & yes & yes & yes & yes & yes & yes & yes \\
Year effects & no & yes & yes & yes & no & yes & yes & yes \\
Add. controls & no & no & no & yes & no & no & no & yes \\
Observations & 382 & 382 & 382 & 382 & 382 & 382 & 382 & 382 \\
(pseudo) $R^{2}$ & 0.037 & 0.155 & 0.149 & 0.377 & 0.013 & 0.095 & 0.095 & 0.261 \\
\hline
\end{tabular}

Notes: Heteroscedasticity robust standard errors in brackets. Basic controls: Auditor election, performance audits, auditor removal procedure, real per capita state debt, state population, state income per capita, unemployment rate, fraction of aged, fraction of school-aged, dummy for southern states. Add. controls: population density, balanced budget requirement, voter initiative. Significance level: ${ }^{*} 0.05<p<0.1$, ***0.01<p<0.05, ${ }^{* * *} p<0.01$. Source: Own calculations

Dependent variable: State credit rating 1990-1999

fected by the inclusion of the squared term and remains very close to the previous estimates. Again, the inclusion of governor term limits does not affect the results.

Similar to the previously reported results, the estimated effect of fixed auditor terms does not yield clear results and is highly sensitive to specification changes. All remaining control variables follow the discussed patterns and are in line with standard research on the US state level.

In summary I find strong results for the influence of auditor term limits. The estimates consistently show a positive correlation between auditor term limits and state credit ratings suggesting that states that have adopted a term limit (after the second four-year term) feature significantly higher credit ratings. Compared to states without such a term limit, the difference is on average a roughly 0.8 to 1 notch higher credit rating (e.g., AA to AA+). This effect is not only statistically significant but also economically relevant. The concern that the result is driven by the practice of a state to generally limit office terms seems not valid, since the results are unchallenged by the inclusion of governor term limits in the regression framework. The theoretical discussion showed that there are arguments in favor of, as well as against, term limits. On the one hand, a binding term limit might induce auditors not to keep up with new developments and reduce specific investments in expertise due to the shorter time horizon, and they might provide incentives to conceal audit specifics from his or her successor. On the other hand, a binding term limit might supply incentives to be even more rigorous and disclose information that would reduce the chances of being reappointed. The empirical findings support the second view in that auditor term limits and GOB ratings are positively correlated. 
Table 4 Sub-sample of states with fixed auditor terms: the effect of auditor term length and term limits on state GOB ratings (Moody's, Fitch and S\&P) from 1990-1999

\begin{tabular}{|c|c|c|c|c|c|c|}
\hline \multirow{2}{*}{$\begin{array}{l}\text { Estimation } \\
\text { method }\end{array}$} & $\mathrm{RE}$ & RE & RE & RE-Tobit & RE-Tobit & RE-Tobit \\
\hline & (1) & (2) & (3) & (4) & (5) & (6) \\
\hline Term length & $\begin{array}{l}-0.001 \\
(0.025)\end{array}$ & $\begin{array}{l}-0.001 \\
(0.024)\end{array}$ & $\begin{array}{l}-0.007 \\
(0.024)\end{array}$ & $\begin{array}{l}-0.001 \\
(0.020)\end{array}$ & $\begin{array}{c}-0.001 \\
(0.019)\end{array}$ & $\begin{array}{l}-0.007 \\
(0.017)\end{array}$ \\
\hline$(\text { Term length })^{2}$ & $\begin{array}{c}-0.000 \\
(0.003)\end{array}$ & $\begin{array}{l}-0.000 \\
(0.003)\end{array}$ & $\begin{array}{l}0.000 \\
(0.003)\end{array}$ & $\begin{array}{l}-0.000 \\
(0.002)\end{array}$ & $\begin{array}{c}-0.000 \\
(0.002)\end{array}$ & $\begin{array}{l}0.000 \\
(0.001)\end{array}$ \\
\hline Term limit & $\begin{array}{l}0.041^{* * *} \\
(0.012)\end{array}$ & $\begin{array}{l}0.052^{* * *} \\
(0.012)\end{array}$ & $\begin{array}{l}0.042^{* * *} \\
(0.011)\end{array}$ & $\begin{array}{l}0.040^{* * *} \\
(0.015)\end{array}$ & $\begin{array}{l}0.051^{\text {*** }} \\
(0.015)\end{array}$ & $\begin{array}{l}0.039 * * * \\
(0.014)\end{array}$ \\
\hline Basic controls & yes & yes & yes & yes & yes & yes \\
\hline Year effects & no & yes & yes & no & yes & yes \\
\hline Add. controls & no & no & yes & no & no & yes \\
\hline Observations & 258 & 258 & 258 & 258 & 258 & 258 \\
\hline (pseudo) $R^{2}$ & 0.410 & 0.472 & 0.559 & 0.185 & 0.298 & 0.384 \\
\hline
\end{tabular}

Notes: Heteroscedasticity robust standard errors in brackets. Basic controls: Auditor election, performance audits, auditor removal procedure, real per capita state debt, state population, state income per capita, unemployment rate, fraction of aged, fraction of school-aged, dummy for southern states. Add. controls: population density, balanced budget requirement, voter initiative. Significance level: ${ }^{*} 0.05<p<0.1$, *** $0.01<p<0.05$, *** $p<0.01$. Source: Own calculations

Dependent variable: State credit rating 1990-1999

The findings on the influence of auditor term length on credit ratings are not unequivocal, since the estimates are not particularly robust. If the estimates are statistically significant I tend to find negative correlations between office term length and credit ratings suggesting that longer terms are associated with lower credit ratings. However, there is no evidence for a quadratic relationship between auditor term length and credit ratings and a final interpretation of the this relationship is not possible.

\section{Conclusion}

Controlling government agents is a major challenge in democratic government systems. In order to reduce information asymmetries between the principal and its agents, agents have to disclose information. However, disclosure requirements are ineffective if the information provided is not accurate and timely. Therefore, disclosure requirements must be backed by independent review. Review of financial information is usually conducted by public auditing institutions, which are supposed to verify and certify financial statements issued by the government. If the audits are of poor quality or the auditor is not independent from the government financial statements lose credibility. From the auditing literature in the corporate sector it is well known that auditor independence is influenced by the duration of the auditor-client relationship. This paper contributes to our understanding of the influence of public audits on policy outcomes by analyzing the influence of auditor term length and term limits on financial markets' perception of the state of public finances. This paper is one of the first attempts to test the influence of auditor characteristics empirically by assembling a unique dataset at the US state level. 
After discussing the influence of auditor term length and term limits on governmental performance from a theoretical perspective, by exploiting available evidence from legislative and executive mandates as well as from research on corporate sector auditing, I turn to the analysis of actual data on US state auditors. Every US state adopts a public auditing institution analyzing official financial statements. I take advantage of the variation in the institutional design of these audit offices across the states. Some state auditors are elected and some are appointed, both typically for a predetermined fixed period of time, and some states feature term limits. The study focuses on the impact of auditor term length and term limits on the state of public finances measured by state General Obligation Bond ratings.

Focusing on the influence of auditor term length on public sector performance, the optimal term length cannot be directly inferred from the available literature on legislative or corporate auditor mandates. However, the theoretical arguments point to a non-linear relationship between term length and outcomes, since a lack of expertise for short terms as well as a lack of accountability for extended terms seem to weaken auditors' contribution to reducing the agency problem. The results from the empirical analyses are not conclusive and a final interpretation of the overall effect of term length including the linear and the quadratic effects is not possible. For the impact of auditor term limits, I consistently find a strong positive and statistically significant correlation between auditor term limits and state credit ratings. States in which a term limit constrains auditor tenure to a maximum of eight years (two consecutive four years terms) have significantly higher credit ratings.

Acknowledgements I would like to thank Reiner Eichenberger, Bruno Frey, and Andrei Shleifer for helpful discussions and feedback on an early version of this paper as well as participants of the Annual Meeting of the European Economic Association 2009, the Verein für Sozialpolitik 2009 and three anonymous referees for their comments. I would like to thank the United States National Association of State Auditors, Comptrollers and Treasurers (NASACT), especially Sherri Rowland for providing support and answering my questions. I would also like to thank Shanna Rose at NYU and Jim Alt at Harvard for sharing their data, and Moody's Investor Services and Fitch Rating, especially Douglas Offerman, for making rating information available.

\section{Appendix}

Table 5 Auditor variable description

Term length

Official auditor term length. Code: official term length in years; if the auditor serves 'at pleasure of legislature, legislative committee, etc.' then coded as 0

Term limit

Binding term limit. Code: 0 if no term limit; 1 if there is a term limit (some states have a limit of 2 terms of 4 years).

\section{Removal procedure}

Removal procedure for agency head. Code: 0 if single committee or public official can remove agency head, 1 if simple majority vote in both legislative chambers required, 2 if supermajority required in both chambers or if special procedures required (e.g., impeachment with supermajority in at least one house, or involving judicial branch), 3 if agency head cannot be removed during official term.

Auditor elected

Selection procedure for agency head. Possible procedures: Elected by the citizens; appointed by the legislature, legislative committee, the executive. Code: 1 if elected by the citizens; 0 if appointed. 
Table 5 (Continued)

Performance audits

Index adding all 3 types of performance audits: Economy \& Efficiency, Program, and Compliance audits.

Economy \& efficiency audits

Economy \& efficiency audit. Code: 1 if economy and efficiency audit is conducted; 0 otherwise

Program audits

Program audit. Code: 1 if program audit is conducted; 0 otherwise

Compliance audits

Compliance only audit. Code: 1 if compliance audit is conducted; 0 otherwise

Notes: Main source of information on US state auditing institutions:

Auditing in the States: A Summary. National Association of State Auditors, Comptrollers and Treasurers (NASACT) $(1989,1992,1996,2000)$

For more information on the construction of the dataset see Schelker (2008)

Table 6 Summary statistics

\begin{tabular}{|c|c|c|c|}
\hline Variable & Min.-Max. & $\begin{array}{l}\text { Sample mean } \\
\text { (Std. dev.) }\end{array}$ & Description \\
\hline State credit rating & $(-0.350)-(-0.047)$ & $\begin{array}{l}-0.129 \\
(0.058)\end{array}$ & $\begin{array}{l}\text { Moody's \& Fitch normalized state general } \\
\text { obligation bond rating (highest rating } \\
\text { (AAA }=-1, \mathrm{AA}+=-2, \mathrm{AA}=-3 \text {, etc., then } \\
\text { normalized to a range between }-1 \text { and } 0 \text { ) }\end{array}$ \\
\hline Term length & $0-10$ & $\begin{array}{l}3.037 \\
(2.628)\end{array}$ & Office term length of auditor in years \\
\hline Term limit & $0 / 1$ & $\begin{array}{l}0.088 \\
(0.284)\end{array}$ & Auditor faces term limit (1), otherwise (0) \\
\hline Fixed term & $0 / 1$ & $\begin{array}{l}0.678 \\
(0.468)\end{array}$ & $\begin{array}{l}\text { If office term length defined (1), if auditor } \\
\text { serves at pleasure of appointing body }(0)\end{array}$ \\
\hline Auditor elected & $0 / 1$ & $\begin{array}{l}0.353 \\
(0.478)\end{array}$ & $\begin{array}{l}\text { Auditor is elected by the citizens ( } 1) \text {, auditor } \\
\text { is appointed by the legislature ( } 0)\end{array}$ \\
\hline Performance audits & $0-3$ & $\begin{array}{l}1.853 \\
(1.128)\end{array}$ & Index of performance audits conducted \\
\hline Auditor removal & $0-3$ & $\begin{array}{l}1.22 \\
(0.934)\end{array}$ & $\begin{array}{l}\text { Index capturing various removal procedures } \\
\text { for the state auditor. }\end{array}$ \\
\hline Government debt & $2366.41-23575.21$ & $\begin{array}{l}5053.18 \\
(2483.51)\end{array}$ & Real per capita government debt in USD \\
\hline State population & $550000-2.00 \mathrm{E}+07$ & $\begin{array}{l}5343362 \\
(4622413)\end{array}$ & Total state population \\
\hline State income & $10023.86-22913.7$ & $\begin{array}{l}14677.58 \\
(2371.28)\end{array}$ & Real per capita state income in USD \\
\hline Unemployment & $2.7-11.3$ & $\begin{array}{l}5.725 \\
(1.491)\end{array}$ & Unemployment rate \\
\hline Aged & $0.084-0.188$ & $\begin{array}{l}0.128 \\
(0.018)\end{array}$ & Fraction of the aged population $(65+)$ \\
\hline
\end{tabular}


Table 6 (Continued)

\begin{tabular}{llll}
\hline Variable & Min.-Max. & $\begin{array}{l}\text { Sample mean } \\
\text { (Std. dev. })\end{array}$ & Description \\
\hline Kids & $0.153-0.269$ & $\begin{array}{l}0.187 \\
(0.018)\end{array}$ & Fraction of school-aged population (5-17) \\
& $0.966-1082.702$ & $\begin{array}{l}210.497 \\
(257.882)\end{array}$ & $\begin{array}{l}\text { Population density (population per square } \\
\text { mile) }\end{array}$ \\
Population density & $0 / 1$ & $\begin{array}{l}0.569 \\
(0.496)\end{array}$ & $\begin{array}{l}\text { Balanced budget requirement (no carry-over } \\
\text { rule) } \\
\text { Voter initiative available (1), otherwise (0) }\end{array}$ \\
Voter initiative & $0 / 1$ & $\begin{array}{l}0.380 \\
(0.486)\end{array}$ & \\
\hline
\end{tabular}

\section{References}

Acemoglu, D., \& Gietzmann, M. B. (1997). Auditor independence incomplete contracts and the role of legal liability. European Accounting Review, 6(3), 355-375.

Alesina, A., \& Perotti, R. (1996). Fiscal discipline and the budget process. American Economic Review, 86(2), 401-407.

Alt, J. E., \& Dreyer Lassen, D. (2006). Fiscal transparency, political parties, and debt in OECD countries. European Economic Review, 50, 1403-1439.

Alt, J. E., Dreyer Lassen, D., \& Skilling, D. (2002). Fiscal transparency gubernatorial approval, and the scale of government: evidence from the states. State Politics and Policy Quarterly, 2(3), 230-250.

Alt, J. E., Dreyer Lassen, D., \& Rose, S. (2006). The causes of fiscal transparency: evidence from the American states. IMF Staff Papers.

Antle, R. (1984). Auditor independence. Journal of Accounting Research, 22(1), 1-20.

Baiman, S., Evans, H. H. III, \& Nagarajan, N. J. (1991). Collusion in auditing. Journal of Accounting Research, 29(1), 1-18.

Barro, R. (1973). The control of politicians, an economic model. Public Choice, 14, 19-42.

Bazerman, M. H., Loewenstein, G., \& Moore, D. A. (2002). Why good accountants do bad audits. Harvard Business Review (November Issue), 96-102.

Bebchuk, L. A. (2007). The myth of the shareholder franchise. Virginia Law Review, 93, 675-732.

Benson, E. D., \& Marks, B. R. (2007). Structural deficits and state borrowing costs. Public Budgeting and Finance (Fall), 1-18.

Benson, E. D., Marks, B. R., \& Raman, K. K. (1986). Municipal borrowing costs and the differential impact of accounting information across ratings categories. Research in Governmental and Nonprofit Accounting, 2, 261-273.

Benz, M., \& Frey, B. S. (2007). Corporate governance: what can we learn from public governance? Academy of Management Review, 32(1), 92-104.

Besley, T., \& Case, A. (1995). Does electoral accountability affect economic policy choices? Evidence from gubernatorial term limits. Quarterly Journal of Economics, 110(3), 769-798.

Besley, T., \& Case, A. (2003). Political institutions and policy choices: evidence from the United States. Journal of Economic Literature, 41, 7-73.

Bohn, H., \& Inman, R. P. (1996). Balanced budget rules and public deficits: evidence from the U.S. states. NBER Working Paper 5533.

Bolton, P., \& Dewatripont, M. (2005). Contract theory. Cambridge: MIT Press.

Buchanan, J. M., \& Congleton, R. D. (1994). The incumbency dilemma and rent extraction by legislators. Public Choice, 79, 47-60.

Capeci, J. (1991). Credit risk, credit ratings, and municipal bond yields: a panel study. National Tax Journal, 44, 41-56.

Comunale, C. L., \& Sexton, T. R. (2005). Mandatory auditor rotation and retention: impact on market share. Managerial Auditing Journal, 20(3), 235-248.

Dal Bo, E., \& Rossi, M. (2008). Term length and political performance. NBER Working Paper 14511.

Daniel, K., \& Lott, J. Jr. (1997). Term limits and electoral competitiveness: evidence from California's state legislative races. Public Choice, 90, 165-184. 
Davidson, W. N. III, Jiraporn, P., \& DaDalt, P. (2006). Causes and consequences of audit shopping: an analysis of auditor opinion, earnings management, and auditor changes. Quarterly Journal of Business and Economics, 45(1-2), 69-87.

Depken, C. A., \& Lafountain, C. L. (2006). Fiscal consequences of public corruption: empirical evidence from state bond ratings. Public Choice, 126, 75-85.

Dick, A. R., \& Lott, J. R. Jr. (1993). Reconciling voters' behavior with legislative term limits. Journal of Public Economics, 50(1), 1-14.

Dopuch, N., King, R. R., \& Schwartz, R. (2001). An experimental investigation of retention and rotation requirements. Journal of Accounting Research, 39(1), 93-117.

Eichenberger, R. (1994). The benefits of federalism and the risk of overcentralization. Kyklos, 47, 403-420.

Eichenberger, R., \& Schelker, M. (2007). Independent and competing agencies: an effective way to control government. Public Choice, 130, 79-98.

Ferejohn, J. (1986). Incumbent performance and electoral control. Public Choice, 50, 5-26.

Ferejohn, J. (1999). Accountability and authority: toward a theory of political accountability. In A. Przeworski, S. C. Stokes, \& B. Manin (Eds.) Democracy, accountability, and representation (pp. 131-153). Cambridge: Cambridge University Press.

Ferraz, C., \& Finan, F. (2008). Exposing corrupt politicians: the effect of Brazil's publicly released audits on electoral outcomes. Quarterly Journal of Economics, 123(2), 703-745.

Franklin, D., \& Westin, T. (1998). Predicting the institutional effect of term limits. Public Choice, 96, 381393.

Frechette, G. (2001a). Random-effects ordered probit (sg158). Stata Technical Bulletin, 59, 23-27.

Frechette, G. (2001b). Update to random-effects ordered probit (sg158:1). Stata Technical Bulletin, 61, 12.

Frey, B. S. (1994). Supreme Auditing Institutions: a politico-economic analysis. European Journal of Law and Economics, 1, 169-176.

Gietzmann, M. B., \& Sen, P. K. (2002). Improving auditor independence through selective mandatory rotation. International Journal of Accounting, 6, 183-210.

Glaeser, E. L. (1997). Self-imposed term limits. Public Choice, 93, 389-394.

Gosh, A., \& Moon, D. (2005). Auditor tenure and perception of audit quality. The Accounting Review, 80(2), 585-612.

Johnson, J. M., \& Crain, W. M. (2004). Effects of term limits on fiscal performance: evidence from democratic nations. Public Choice, 119, 73-90.

Johnson, C. L., \& Kriz, K. A. (2005). Fiscal institutions, credit ratings, and borrowing costs. Public Budgeting and Finance (Spring), 84-103.

Johnson, V. E., Khurana, I. K., \& Reynolds, J. K. (2002). Audit-firm tenure and the quality of financial reports. Contemporary Accounting Research, 19(4), 637-660.

Khalil, F., \& Lawarée, J. (2006). Incentives for corruptible auditors in the absence of commitment. Journal of Industrial Economics, 54(2), 269-291.

Lopez, E. J. (2003). Term limits: causes and consequences. Public Choice, 114, 1-56.

Mansi, S. A., Maxwell, W. F., \& Miller, D. P. (2004). Does auditor quality and tenure matter to investors? Evidence from the bond market. Journal of Accounting Research, 42(4), 755-793.

Maskin, E., \& Tirole, J. (2004). The politician and the judge: accountability in government. American Economic Review, 94(4), 1034-1054.

Matsusaka, J. G. (2004). For the many or the few. The initiative, public policy, and American democracy. Chicago: The University of Chicago Press.

Mautz, R. K., \& Sharaf, H. A. (1961). The philosophy of auditing. American accounting association monograph No. 6. Sarasota, Florida.

Mayhew, B. W., \& Pike, J. E. (2004). Does investor selection of auditors enhance auditor independence? The Accounting Review, 79(3), 797-822.

Milesi-Ferretti, G. M. (2004). Good, bad or ugly? On the effects of fiscal rules with creative accounting. Journal of Public Economics, 88, 377-394.

Myers, J. N., Myers, L. A., \& Omer, T. C. (2003). Exploring the term of the auditor-client relationship and the quality of earnings: a case for mandatory auditor rotation? The Accounting Review, 78(3), 779-799.

NASACT (1989, 1992, 1996, 2000). Auditing in the states: a summary. Lexington: National Association of State Auditors, Comptrollers and Treasurers (NASACT).

Olken, B. A. (2007). Monitoring corruption: evidence from a field experiment in Indonesia. Journal of Political Economy, 115(2), 200-249.

Poterba, J. M. (1994). State responses to fiscal crises: the effects of budgetary institutions and politics. Journal of Political Economy, 102(4), 799-821.

Poterba, J. M. (1996). Budget institutions and fiscal policy in the U.S. states. American Economic Review, $86(2), 395-400$. 
Poterba, J. M., \& Rueben, K. S. (2001). Fiscal news, state budget rules, and tax-exempt bond yields. Journal of Urban Economics, 50, 537-562.

Schelker, M. (2008). Making auditors effective: theory, evidence, perspectives. Baden-Baden: Nomos.

Schelker, M. (2009). Auditor terms and term limits in the public sector: evidence from the US states. CREMA Working Paper No. 2009-19.

Schelker, M., \& Eichenberger, R. (2003). Starke Rechnungsprüfungskommissionen: Wichtiger als direkte Demokratie und Föderalismus? Ein erster Blick auf die Daten. Swiss Journal of Economics and Statistics, 139(3), 351-373.

Smart, M., \& Sturm, D. M. (2006). Term limits and electoral accountability. CEPR Working Paper.

Tirole, J. (1986). Hierarchies and bureaucracies: on the role of collusion in organizations. Journal of Law, Economics and Organization, 2(2), 181-214.

Titiunik, R. (2008). Drawing your senator from a jar: term length and legislative behavior. Mimeo, UC Berkeley.

von Hagen, J., \& Harden, I. J. (1995). Budget processes and commitment to fiscal discipline. European Economic Review, 39, 771-779.

von Hagen, J., \& Wolff, G. B. (2004). What do deficits tell us about debt? Empirical evidence on creative accounting with fiscal rules in the EU. Deutsche Bundesbank Discussion Papers 38/2004.

Wallack, J. S. (2007). Picking numbers: the highs and lows of revenue estimating. Working Paper, UC San Diego. 